\title{
Retinoblastoma Pathologic Regional Lymph Nodes TNM Finding v7
}

National Cancer Institute

\section{Source}

National Cancer Institute. Retinoblastoma Pathologic Regional Lymph Nodes TNM

Finding v7. NCI Thesaurus. Code C88739.

A pathologic finding about one or more characteristics of retinoblastoma, following the rules of the TNM AJCC V7 classification system as they pertain to staging of regional lymph nodes. 